\title{
Effects of chemical modification with glutaraldehyde on the weathering performance of Scots pine sapwood
}

\author{
Zefang Xiao $\cdot$ Yanjun Xie $\cdot$ Stergios Adamopoulos $•$ \\ Carsten Mai
}

Received: 3 April 2011/Published online: 30 August 2011

(C) The Author(s) 2011. This article is published with open access at Springerlink.com

\begin{abstract}
Scots pine sapwood was treated with glutaraldehyde (GA) in aqueous solution using magnesium chloride as a catalyst in order to evaluate the durability towards weathering. Infrared spectroscopy suggested that GA treatment increased the photo-stability of lignin during artificial weathering of micro-veneers in a QUV over $168 \mathrm{~h}$; photo-protection increased with increasing GA concentration. In comparison with the unmodified controls, GA-modified pine micro-veneer strips exhibited a lower tensile strength loss measured in a zero-span mode in the course of weathering. During 18 months of outdoor exposure, GA-modified pine wood boards exhibited a lower moisture content and water uptake than the unmodified ones. GA treatment also clearly restricted the penetration of blue stain fungi into deeper layers of wood. On the macroscopic scale, the surface of the GA-modified boards was significantly smoother due to less erosion, cracking and minor peeling of tracheids. Scanning electron microscopy further revealed that individual tracheids were detached from the cell compound and then washed away from the unmodified wood surface, whereas tracheids on surfaces of GA-modified wood remained in the tissue compound but displayed many axial and transversal cracks.
\end{abstract}

\footnotetext{
Z. Xiao · S. Adamopoulos · C. Mai $(\square)$

Wood Biology and Wood Products, Burckhardt Institute, Georg-August-University of Göttingen, Büsgenweg 4, 37077 Göttingen, Germany

e-mail: cmai@gwdg.de

\section{Y. Xie}

Key Laboratory of Bio-based Material Science and Technology, Ministry of Education, Northeast Forestry University, 26 Hexing Road, Harbin, China

S. Adamopoulos

Department of Forestry and Management of Natural Environment,

Technological Educational Institute of Larissa, 43100 Karditsa, Greece
} 


\section{Introduction}

Wood is susceptible to abiotic erosion and biotic attack when it is exposed outdoors. As an effective protecting strategy, chemical modification can partly alter the polymeric structure of the wood cell wall and thereby improve the durability. Chemical modification enhances dimensional stabilisation by depositing a chemical in the wood cell wall (bulking effect) and/or by cross-linking the cell wall polymers (Hill 2006). Several types of chemical modification, which are based on blocking hydroxyl groups of cell wall polymers, have been assessed with regard to their weathering performance (Evans 2009). Wood modified with butylenes, methyl isocyanate or butylene oxide to weight percentage gains (WPGs) in excess of $25 \%$ was eroded to the same extent as unmodified controls during artificial accelerated weathering (Rowell et al. 1981; Feist and Rowell 1982). Acetylation was found to reduce the weight loss of veneers during weathering compared to unmodified controls (Feist et al. 1991). Evans et al. (2000), however, reported that veneers acetylated to low WPGs (5 and 10\%) displayed larger losses in weight and tensile strength during weathering, while at higher WPG (20\%), weight losses and degradation of holocellulose were lower than in the unmodified controls. Esterification of veneers with phthalic, succinic and maleic anhydride did not reduce weight losses of veneers during artificial weathering and induced greater losses in tensile strength during accelerated weathering as compared to the unmodified controls (Evans 1998). Esterification of veneers with benzoyl chloride (Evans et al. 2002) and vinyl benzoate (Jebrane et al. 2009) led to photostabilisation of lignin; however, a high WPG of $70 \%$ (benzoyl chloride) and above $30 \%$ (vinyl benzoate) was necessary to achieve effective protection.

Few studies report on the weathering performance of wood modified with crosslink agents. Recently, 1,3-dimethylol-4,5-dihydroxyethyleneurea (DMDHEU), a cross-link agent used to impart easy-care properties to textiles, has been tested regarding its effect on the weathering performance of modified wood. DMDHEU treatment of thin veneer strips partially reduced the degradation of lignin and cellulose and stabilised the wood cell walls during artificial weathering (Xie et al. 2005). During outdoor weathering, DMDHEU enhanced the dimensional stability and reduced water uptake, deformation and crack formation of Scots pine boards (Xie et al. 2008). Still, the main reaction of DMDHEU in wood is assumed to be the auto-condensation in the cell wall rather than cross-link of cell wall polymers; the treatment is therefore referred to as impregnation modification (Hill 2006).

Glutaraldehyde (GA; pentane-1,5-dial) is a dialdehyde which can in principle react with four hydroxyl groups in the presence of an acidic catalyst and is thus able to cross-link cell wall polymers in wood. Accordingly, GA has been used as a woodmodifying agent using sulphur dioxide gas as a catalyst (Yasuda and Minato 1994; Yusuf 1996). Sulphur dioxide gas, however, is more difficult to control for wood treatment as compared to an aqueous system. Recently, an aqueous treating system containing GA and magnesium chloride as a catalyst has been successfully applied to promote the cross-link reaction (Xiao et al. 2010a, b).

The GA-modified wood exhibited improved dimensional stability and reduced moisture sorption as compared to the unmodified wood (Weaver et al. 1960; Yusuf 
1996; Yasuda and Minato 1994; Xiao et al. 2010a). The anti-swelling efficiency (ASE) of GA-modified wood was higher than $60 \%$, and the equilibrium moisture content (EMC) and the capillary water uptake considerably decreased (Yasuda and Minato 1994; Xiao et al. 2010a; Xie et al. 2011). Due to the high dimensional stability, two-ply laminated veneers modified with GA exhibited fewer surface cracks than the unmodified controls after 24 weeks of exposure to natural weathering or $720 \mathrm{~h}$ of artificial weathering (Yusuf 1996). GA-modified wood (catalysed with sulphur dioxide) was shown to resist the decay by the brown-rot fungus Tyromyces palustris and the white-rot fungus Trametes versicolor.

The aim of this study was to evaluate the effect of GA treatments in aqueous solution with $\mathrm{MgCl}_{2}$ as a catalyst on the resistance of pine wood towards artificial and natural weathering.

\section{Materials and methods}

Chemicals

Glutaraldehyde (GA) was supplied as a 50\% aqueous solution in technical quality by BASF (Ludwigshafen, Germany). Magnesium chloride hexahydrate $\left(\mathrm{MgCl}_{2} \cdot 6 \mathrm{H}_{2} \mathrm{O}\right)$ was of extra purity grade. Acetic acid and sodium acetate were of analytical purity grade purchased from Sigma-Aldrich Chemie GmbH (Munich, Germany).

\section{Wood samples}

Micro-veneers and boards were prepared from industrially kiln-dried $\left(60-70^{\circ} \mathrm{C}\right)$ Scots pine (Pinus sylvestris L.) sapwood. The density of the wood was approximately $0.49 \mathrm{~g} \mathrm{~cm}^{-3}$.

\section{Micro-veneers for artificial weathering test}

Scots pine sapwood blocks with a size of $100 \times 50 \times 15 \mathrm{~mm}^{3}(L \times T \times R)$ were prepared as previously described (Evans 1988). Micro-veneer strips measuring $100 \mathrm{~mm} \times 15 \mathrm{~mm} \times 80 \mu \mathrm{m}(L \times R \times T)$ were sectioned from water-saturated sapwood blocks using disposable microtome blades (Reichert-Jung, Nussloch, Germany) as described previously (Xie et al. 2007, Xie et al. 2010). The thickness of the micro-veneer strips was measured with a digimatic gauge (Mitutoyo, Naucalpan, Mexico).

\section{Wood boards for natural weathering test}

Wood boards selected to test natural weathering were free of knots, cracks and resinous streaks. They were straight-grained and exhibited 3-5 annual rings per $10 \mathrm{~mm}$. The inclination of the annual rings to the surface was 30-45. The wood boards were vertically sawn to a size of $375 \times 90 \times 20 \mathrm{~mm}^{3}(L \times R \times T)$ according 
to EN 927-3 (2006). Some of the boards contained heartwood, but the test surface on the convex side of the growth rings only consisted of sapwood. Heartwood was confined to a zone not exceeding $12 \mathrm{~mm}$ in depth when measured from the rear face.

\section{Treatment of wood}

Scots pine micro-veneers were impregnated with aqueous acetate buffer $(\mathrm{pH} \mathrm{4.5,}$ $0.1 \mathrm{~mol} \mathrm{l}^{-1}$ ) solutions containing $0,0.4,1.2$ and $2.0 \mathrm{~mol}^{-1} \mathrm{GA}$ and $2.5 \mathrm{wt} \%$ $\mathrm{MgCl}_{2} \cdot 6 \mathrm{H}_{2} \mathrm{O}$ (final concentration) under vacuum conditions (100 mbar, $30 \mathrm{~min}$ ) and ambient pressure (10 $\mathrm{min})$.

Scots pine wood boards were impregnated with $0.4,1.2$ and $2.0 \mathrm{~mol} \mathrm{l}^{-1} \mathrm{GA}$ and $6.0 \mathrm{wt} \% \mathrm{MgCl}_{2} \cdot 6 \mathrm{H}_{2} \mathrm{O}$ (related to $\mathrm{GA}$ ) in aqueous acetate buffer $(0.1 \mathrm{M}, \mathrm{pH} 4.5$ ) using vacuum (100 mbar, $1 \mathrm{~h}$ ) and pressure (10 bar, $2 \mathrm{~h}$ ). After impregnation, the excess solution was blotted off the specimens with tissue paper. The micro-veneers were predried at room temperature for $1 \mathrm{~h}$ and then put into an oven preheated to $60^{\circ} \mathrm{C}$. The temperature was subsequently increased $\left(1^{\circ} \mathrm{C} \times \min ^{-1}\right)$ to $120^{\circ} \mathrm{C}$ and held for $2 \mathrm{~h}$ for final curing.

The wood boards were predried at room temperature ( 3 weeks) at $40^{\circ} \mathrm{C}$ ( 1 week), at $80^{\circ} \mathrm{C}$ ( 1 week) and finally cured at $120^{\circ} \mathrm{C}$ (1 week). Specimens modified only with acetate buffer served as controls. After conditioning $\left(20^{\circ} \mathrm{C}, 65 \% \mathrm{RH}\right)$ for $24 \mathrm{~h}$, the micro-veneer strips were rinsed with running tap water (approximately $40^{\circ} \mathrm{C}$ ) for $2 \mathrm{~h}$ to remove unreacted $\mathrm{GA}$, acetate and $\mathrm{MgCl}_{2}$. The wood boards were not subjected to leaching. The mass of samples was recorded, and the resulting WPG was calculated as described previously (Hill et al. 2004).

\section{Weathering}

For artificial weathering, all micro-veneer strips were exposed in a QUV machine (Q-Panel, Lab Products, Cleveland, USA). The exposure involved a UV-A light (maximum absorption at $340 \mathrm{~nm} ; 0.77 \mathrm{Wm}^{-2} \mathrm{~nm}^{-1}$ ) from a fluorescent light source over 56 cycles, each including $2.5 \mathrm{~h}$ of UV irradiation at $60^{\circ} \mathrm{C}$ and $30 \mathrm{~min}$ cold water spray (6-7 $\left.1 \mathrm{~min}^{-1}\right)$. Six veneers were used per treatment and exposure time.

Natural weathering was performed according to EN 927-3 (2006). Four boards were used per treatment, which were end-grain-sealed with a commercial sealant (Pyrotect Schutzlack $2 \mathrm{~K}$, Rütgers Organics GmbH, Germany) and then exposed outdoors in Goettingen (Central Germany) for 18 months (September 2008-April 2010).

Infrared spectroscopic analysis

FT-IR spectra of the unmodified and modified micro-veneer strips were recorded after weathering for $0,24,72,96,144$ and $168 \mathrm{~h}$ using a Vektor 22 spectrophotometer (Bruker, Bremen, Germany) operating on 64 scans and at $4 \mathrm{~cm}^{-1}$ resolution. The micro-veneer strips were directly measured using attenuated total 
reflection (ATR) technique (DuraSanplIRIITM, SensIR Technologies, Warrington, UK).

Tensile strength determination

After 0, 24, 72, 96, 144 and $168 \mathrm{~h}$ of artificial weathering, six micro-veneer strips from each treatment were removed from the QUV, and zero-span tensile strength was determined using a Pulmac paper tester (Pulmac International Inc., Middlesex, USA) as described previously (Xie et al. 2005; Evans and Schmalzl 1989). The rate of loading was $70 \mathrm{kPa} \mathrm{s}^{-1}$, and the initial clamping pressure was $0.55 \mathrm{MPa}$. The relative tensile strength retention of the strips after specific weathering periods was related to the tensile strength of the buffer-modified controls. The tensile strength of the controls was set to $100 \%$. The strength losses of the veneer strips due to the GA treatment and due to weathering as well as the total strength loss were calculated after $168 \mathrm{~h}$ of weathering (also based on the unmodified and unweathered controls).

\section{Scanning electron microscopy}

The micro-veneer strips before and after weathering were cut with a razor blade into samples of $7 \times 7 \mathrm{~mm}^{2}(R \times L)$ for radial-sectional observation. A surface layer section from the outside weathered boards $\left(\right.$ ca. $7 \times 7 \mathrm{~mm}^{2}$ ) was carefully removed with a razor blade for microscopic observation. These samples were attached to aluminium stubs and dried overnight in a vacuum oven at $25^{\circ} \mathrm{C}$. The samples were then sputter-coated with a $15-\mathrm{nm}$ layer of platinum and examined using an ultrahigh resolution field emission scanning electron microscope (Hitachi S-4800, Maidenhead, Berkshire, UK) operating at an acceleration voltage of $3 \mathrm{kV}$.

Evaluation of the weathered boards

\section{Water uptake during and after weathering}

About every 3 months, all exposed boards were weighed to determine the moisture content. After 18 months of weathering, the boards were taken and conditioned at $20^{\circ} \mathrm{C}$ and $65 \% \mathrm{RH}$ for 3 weeks. In order to determine the capillary water uptake, the weathered surface of the boards was put on the surface of distilled water in a basin $\left(20^{\circ} \mathrm{C}\right)$; the boards' surface was about $2 \mathrm{~mm}$ under the water surface. The mass of the boards was determined after 1, 2, 6, 12, $24 \mathrm{~h}$, respectively. The results were expressed as water uptake per square meter based on the weathered surface of the boards within the elapsed time.

\section{Surface cracking}

Surface cracking was evaluated according to standard ISO 4628-4 (1982). The evaluation scale ranged from 0 to $5(\mathrm{CR}=0$ : no cracks and $\mathrm{CR}=5$ : dense pattern of cracks). 


\section{Blue stain colonisation}

To observe the penetration of the boards by blue stain fungi, smooth, radial surfaces were prepared using a razor blade and viewed under a S8 APO stereoscope (Leica, Wetzlar, Germany) without external light.

For light microscopy, the boards were sectioned with a GSL 1 sledge microtome (Zürich, Switzerland), taking $15-$ to $20-\mu \mathrm{m}$ radial sections from different positions. Sections were stained with safranin, then mounted on glass slides in Entellan (Merck, Darmstadt, Germany) and examined under an Eclipse 50i light microscope equipped with a digital Sight DS-5M-L1 camera (both Nikon, Düsseldorf, Germany).

\section{Results and discussion}

Weight percentage gain (WPG)

The micro-veneer strips obtained a linear increase in WPG with increasing GA concentration (Fig. 1a). After leaching with water, the WPGs obviously decreased due to removal of wood constituents, sodium acetate, $\mathrm{MgCl}_{2}$ and unreacted GA. Finally, the micro-veneer strips obtained a WPG of 3, 8 and $11 \%$, respectively. The micro-veneer strips modified with $2.5 \% \mathrm{MgCl}_{2} \cdot 6 \mathrm{H}_{2} \mathrm{O}$ exhibited a negative WPG comparable to the unmodified controls after leaching, which can be attributed to the loss of extractives and degraded wood constituents (Fig. 1a).

The WPG of the wood boards reached 5, 14 and 23\%, respectively, but leaching was not performed prior to outdoor exposure (Fig. 1b).

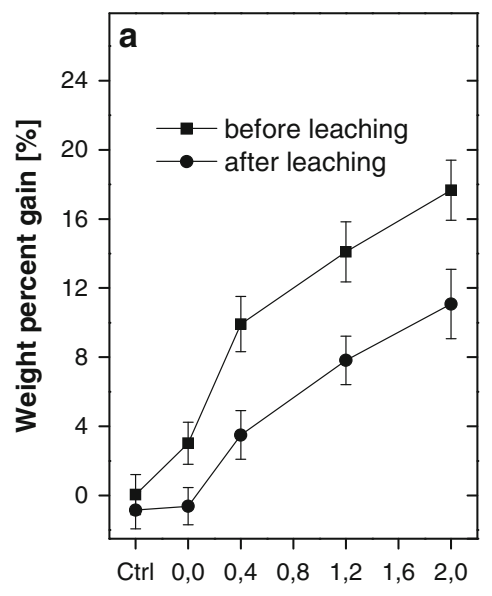

GA concentration $\left[\mathrm{mol} \mathrm{l}^{-1}\right.$ ]

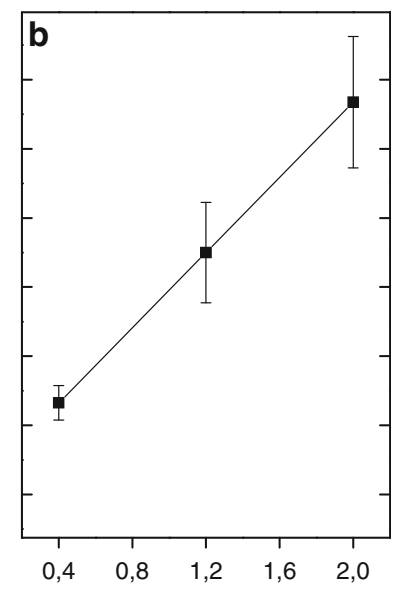

GA concentration $\left[\mathrm{mol} \mathrm{I}^{-1}\right.$ ]

Fig. 1 Weight percentage gain of (a) wood micro-veneers before and after leaching $(n=36 \pm$ SD) and (b) boards without leaching $(n=6 \pm \mathrm{SD})$ 
Infrared spectroscopic analysis during artificial weathering

The infrared spectra of the unmodified veneers show that the absorbance of the carbonyl stretching $\left(1,731 \mathrm{~cm}^{-1}\right)$, the aromatic skeletal stretching $(1,600$ and $\left.1,508 \mathrm{~cm}^{-1}\right)$ in lignin and the $\mathrm{C}-\mathrm{O}$ stretching vibration $\left(1,265 \mathrm{~cm}^{-1}\right)$ in hemicelluloses diminished with the weathering time (Fig. 2a); the aromatic vibration disappeared after $72 \mathrm{~h}$ of weathering. Aromatic groups in lignin attributable to absorption at 1,508 and $1,600 \mathrm{~cm}^{-1}$ are very susceptible to degradation by ultraviolet light (Evans et al. 1996). The decrease of $1,265 \mathrm{~cm}^{-1}$ suggests the degradation of hemicelluloses (Faix et al. 1992; Xie et al. 2005). The cellulosic
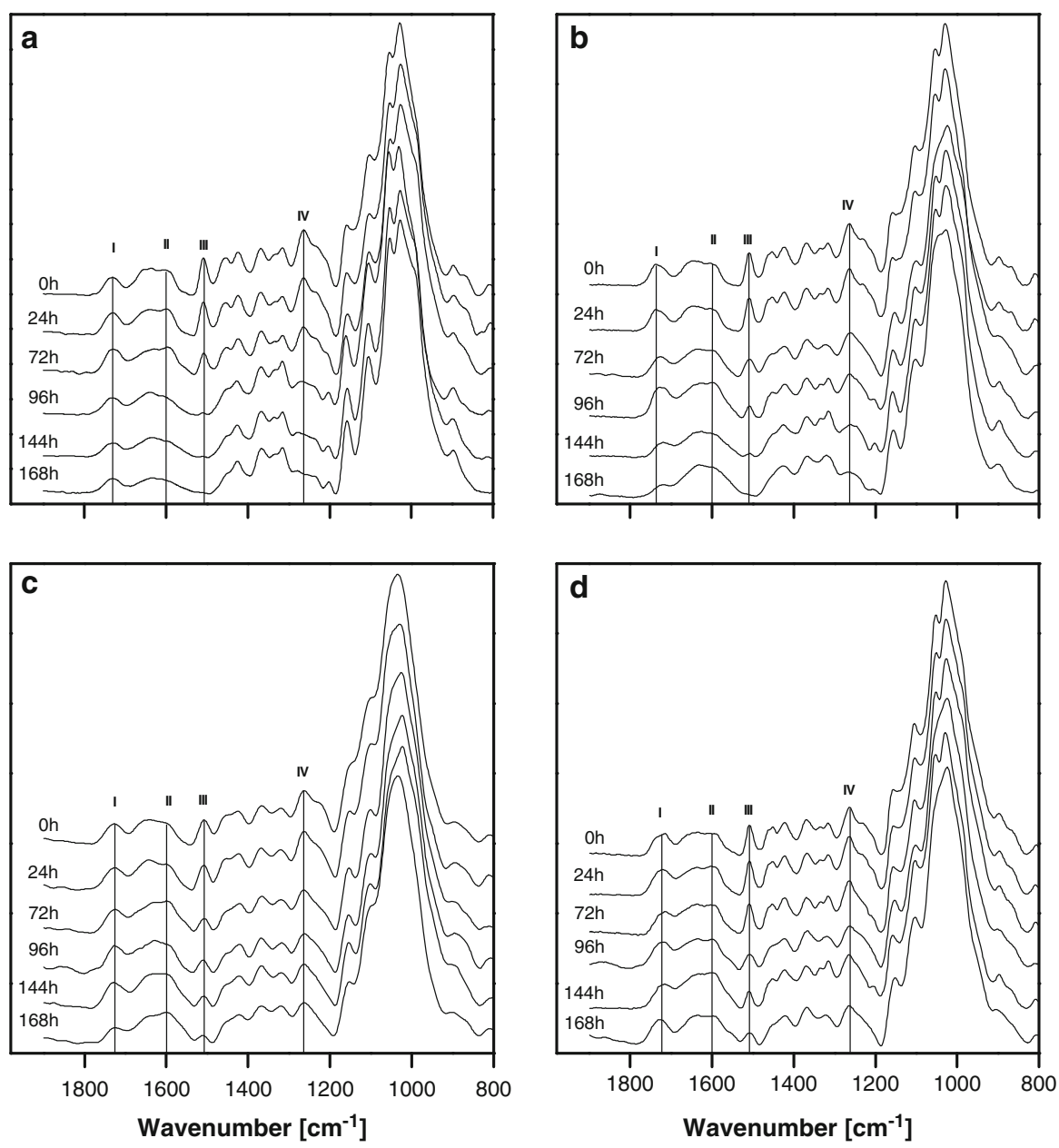

Fig. 2 Infrared spectra of veneers after different weathering times; veneers treated with a acetate buffer, b $0.4 \mathrm{~mol} \mathrm{l}^{-1}$, c $1.2 \mathrm{~mol}^{-1}$, and $\mathbf{d} 2.0 \mathrm{~mol} \mathrm{l}^{-1}$ glutaraldehyde, respectively. Infrared peak assignments: (I) carbonyl stretching; (II, III) aromatic skeletal vibration in lignin; (IV) $\mathrm{C}-\mathrm{O}$ stretching in lignin, acetyl and carbonyl vibration in hemicelluloses 
constituents characterised by the bands at 1,370, 1,315 and 1,160 $\mathrm{cm}^{-1}$ (Chang and Chang 2001) did not exhibit significant changes due to weathering.

Compared to the unweathered and unmodified controls $(0 \mathrm{~h}$ in Fig. $2 \mathrm{a})$, the GA-modified micro-veneer strips exhibited comparable infrared absorbance spectra with any additional peaks due to the treatment $(0 \mathrm{~h}$ in Fig. $2 \mathrm{~b}-\mathrm{d})$. The stability of the carbonyl absorption, the aromatic (lignin) absorption and the $\mathrm{C}-\mathrm{O}$ stretching peaks (hemicelluloses) towards weathering was enhanced with increasing WPG as evidenced by a longer retainment of bands at 1,731, 1,600, 1,508 and 1,265 cm-1 (Fig. 2b-d). Even after $168 \mathrm{~h}$ of weathering, the bands were still present in wood modified with 1.2 and 2.0 M GA (Fig. 2c, d), which suggests that GA treatment restricts the degradation of lignin and the hemicelluloses.

Recently, a slightly enhanced photo-stability of lignin was reported for Scots pine sapwood modified with 1,3-dimethylol-4,5-dihydroxyethyleneurea (DMDHEU) (Xie et al. 2005). The photo-stability of lignin in GA-modified wood was clearly higher and might be attributed to a blocking of phenolic groups in lignin by GA; the latter is assumed to hinder the absorption of UV light and the oxidation of the phenolic groups (Feist and Hon 1984; Schmalzl et al. 1995, 2003). Acetylation to low weight gains, however, was shown to accelerate the degradation of lignin so that blocking of phenolic hydroxyl groups cannot be the reason for the enhanced stability of lignin (Evans et al. 2000). Esterification of Scots pine sapwood with benzoyl chloride (Evans et al. 2002) and vinyl benzoate (Jebrane et al. 2009) was more effective at photo-stabilising lignin at high WPG than GA treatment. This protecting effect, however, is attributable to the ability of the aromatic benzoyl groups to absorb UV light, which is not the case with GA. GA might possibly protect the wood through the reduction in moisture both in the cell walls and in the lumens of wood. In addition, GA-modified wood displayed a clearly lower degree of maximum swelling in water compared to unmodified wood (Xiao et al. 2010a). Thus, GA treatment might decelerate leaching of lignin degradation products and reduce the susceptibility of the inner parts of the wood cells to UV light.

Change in tensile strength during artificial weathering

GA treatment reduced the tensile strength of micro-veneer strips, which exhibited an increased strength loss up to $47 \%\left(2 \mathrm{~mol} \mathrm{l}^{-1} \mathrm{GA}\right)$ with increasing GA concentration $(0 \mathrm{~h}$ in Fig. 3a). Tensile strength loss of micro-veneer strips due to GA treatment was previously attributed to the hydrolysis of cell wall polymers and cross-link by GA (Xiao et al. 2010b). Treatment with the catalyst $\left(\mathrm{MgCl}_{2} \cdot 6 \mathrm{H}_{2} \mathrm{O}\right.$ ) alone also reduced the tensile strength but to a minor degree (approximately 5\%, Fig. 3a), which is due to the hydrolysis of cell wall polysaccharides catalysed by such type of Lewis acid (Xie et al. 2007).

With increasing weathering time, the unmodified and solely catalyst-modified veneer strips continuously lost their strength, suggesting progressively degradation of cell wall polymers, especially of cellulose (Evans 2008). Compared to the untreated and only catalyst-treated veneers, the GA-treated strips, especially those treated with high GA concentration, exhibited much less strength loss during the weathering exposure (Fig. 3a). After $168 \mathrm{~h}$ of weathering, the untreated controls 

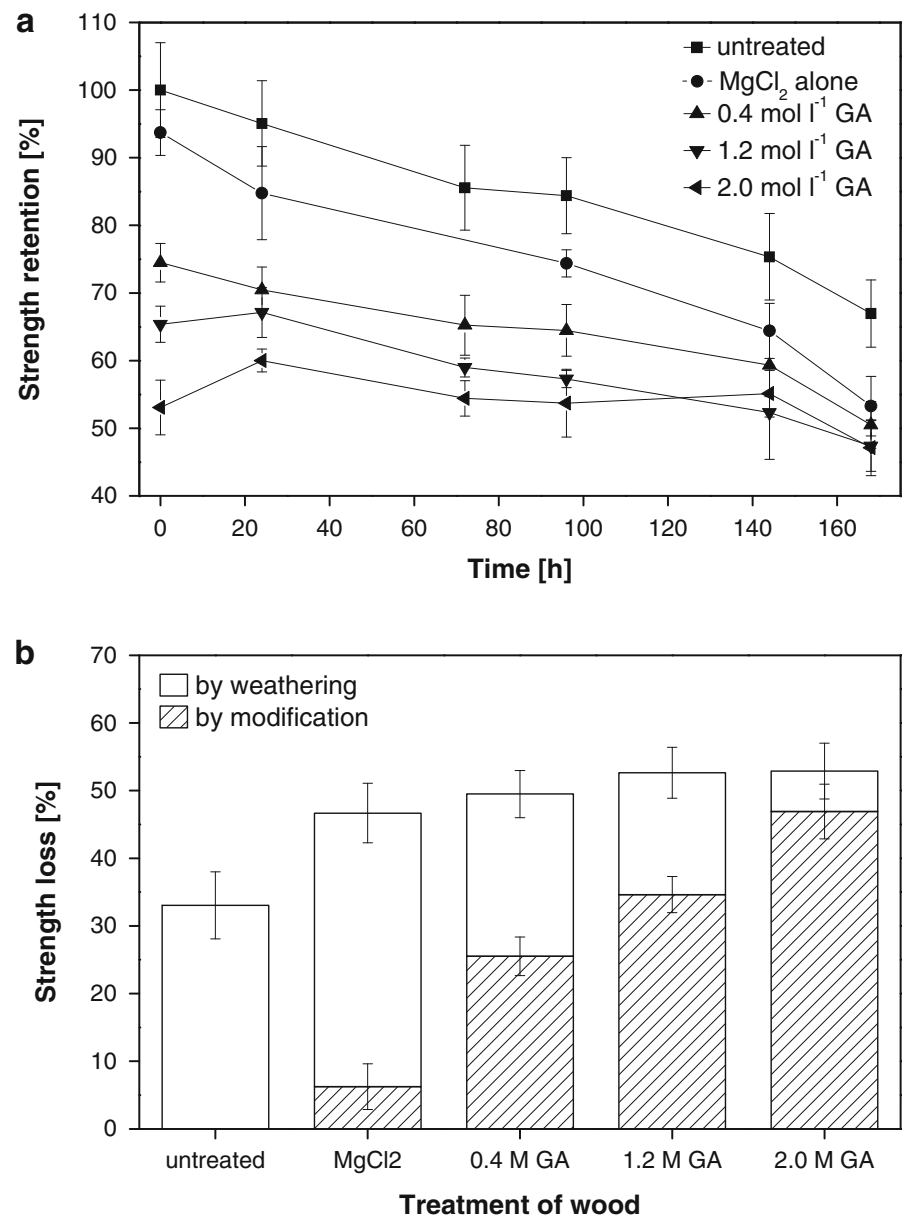

Fig. 3 Tensile strength retention (a) and strength loss (b) of veneers treated in buffer containing $\mathrm{MgCl}_{2} \cdot 6 \mathrm{H}_{2} \mathrm{O}$ (2.5 wt $\%$, final concentration), as well as glutaraldehyde $\left(0.4,1.2\right.$, and $\left.2.0 \mathrm{~g} \mathrm{~mol}^{-1}\right)$ with $\mathrm{MgCl}_{2} \cdot 6 \mathrm{H}_{2} \mathrm{O}$ (2.5 wt\%, final concentration) during artificial weathering in a QUV. Strength loss (b) was assessed after $168 \mathrm{~h}$ weathering. The calculation is based on the tensile strength of the unweathered and unmodified veneers. The $\mathrm{pH}$ value of all treatment solutions was adjusted to 4.5 using acetate buffer $(n=6 \pm \mathrm{SD})$

totally lost $33 \%$ of tensile strength; the micro-veneer strips treated with $\mathrm{MgCl}_{2}$ alone or $\mathrm{GA}$ and $\mathrm{MgCl}_{2}$ displayed a total strength loss of approximately $50 \%$ (Fig. 3b). The contribution of the GA treatment to the total strength loss increased with increasing concentration but that of weathering decreased to a similar degree. The strength loss caused by GA treatment is attributed to the hydrolysis of hemicelluloses and of amorphous cellulose due to the presence of the Lewis acid catalyst $\mathrm{MgCl}_{2}$ and to cross-linking of cell wall polymer by GA (Xiao et al. 2010b). Crystalline cellulose is hardly susceptible to water, chemicals or UV light because of the dense packing of the parallel glucan chains. Probably, a maximum level of 
strength loss was reached because the bulk of the susceptible cell wall polymers were damaged due to the combined effect of GA treatment and weathering. This might be the reason for the levelling off of total strength loss and the reduced degradation of micro-veneer strips through weathering. Further strength losses might only occur due to degradation of crystalline parts of cellulose.

Surface appearance of wood boards after natural weathering

All exposed boards displayed a grey colour, but the modified boards were slightly darker than the unmodified ones (Fig. 4). The surface of unmodified boards exhibited many long, loose hairy fibres and a washboard effect (Fig. 4a). The loose fibres are assumed to be formed due to photo-degradation of the middle lamella followed by washing away of degradation products by rain water resulting in an isolation of the tracheids mainly from earlywood. The washboard effect is attributable to a faster degradation of the earlywood cells than of the latewood cells. After removal of degraded cells of the outer surface layer, underlying cell layers are exposed and further eroded (Feist 1982). Treatment with 0.4 M GA reduced the amount of hairy fibres and the washboard effect (Fig. 4b). The boards modified with higher GA concentrations (1.2 and $2.0 \mathrm{~mol} \mathrm{l}^{-1}$ ) did not show any detached fibres and washboard effect (Fig. 4c, d), which might be explained by the enhanced photoprotection of lignin and hemicelluloses due to GA treatment evidenced by the infrared spectroscopy.

The number of visual cracks on the unmodified surface increased with the exposure time, which were ranked as $\mathrm{CR}=4$ after 18 months of weathering; in the initial 3 months, no visible cracks have been formed on the surface (Table 1). In a previous study, unmodified flat sawn Scots pine boards developed surface cracks very quickly and obtained a $\mathrm{CR}=5$ after 18 months of weathering (Xie et al. 2008). The vertical-grain surface used in this study, however, develops less cracks and minor deformation (warping and cupping) than the flat-grain surface because the degree of swelling in the radial direction is less than in the tangential direction (Williams 2010). Treatment with low GA concentration $\left(0.4 \mathrm{~mol}^{-1}\right)$ reduced surface cracking as compared to the unmodified boards, but still a moderate amount of cracks $(\mathrm{CR}=3)$ has been formed during weathering (Table 1). No visible surface cracking occurred on the boards modified with 1.2 and $2.0 \mathrm{~mol}^{-1} \mathrm{GA}$ within the first 9 months of weathering; afterwards, a few checks and cracks gradually formed resulting in $\mathrm{CR}=2$ after 18 months. The reduction in surface cracking due to GA treatment can mainly be explained by the improved dimensional stability as well as reduced moisture sorption and water uptake reported previously (Xiao et al. 2010b). It was previously shown that photo-stabilisation of wood can reduce surface checking and improve dimensional stability (Evans et al. 2008).

Moisture content during natural weathering

During outdoor exposure, the GA-modified boards exhibited lower moisture content than the controls; the fluctuation of moisture content in the boards modified to higher WPG was less under changing environmental condition (Fig. 5a). The 
Fig. 4 Appearance of untreated wood a and wood treated with b $0.4 \mathrm{~mol} \mathrm{l}^{-1}$, c $1.2 \mathrm{~mol} \mathrm{l}^{-1}$ and d $2.0 \mathrm{~mol}^{-1}$ glutaraldehyde, respectively, after 18 months of weathering
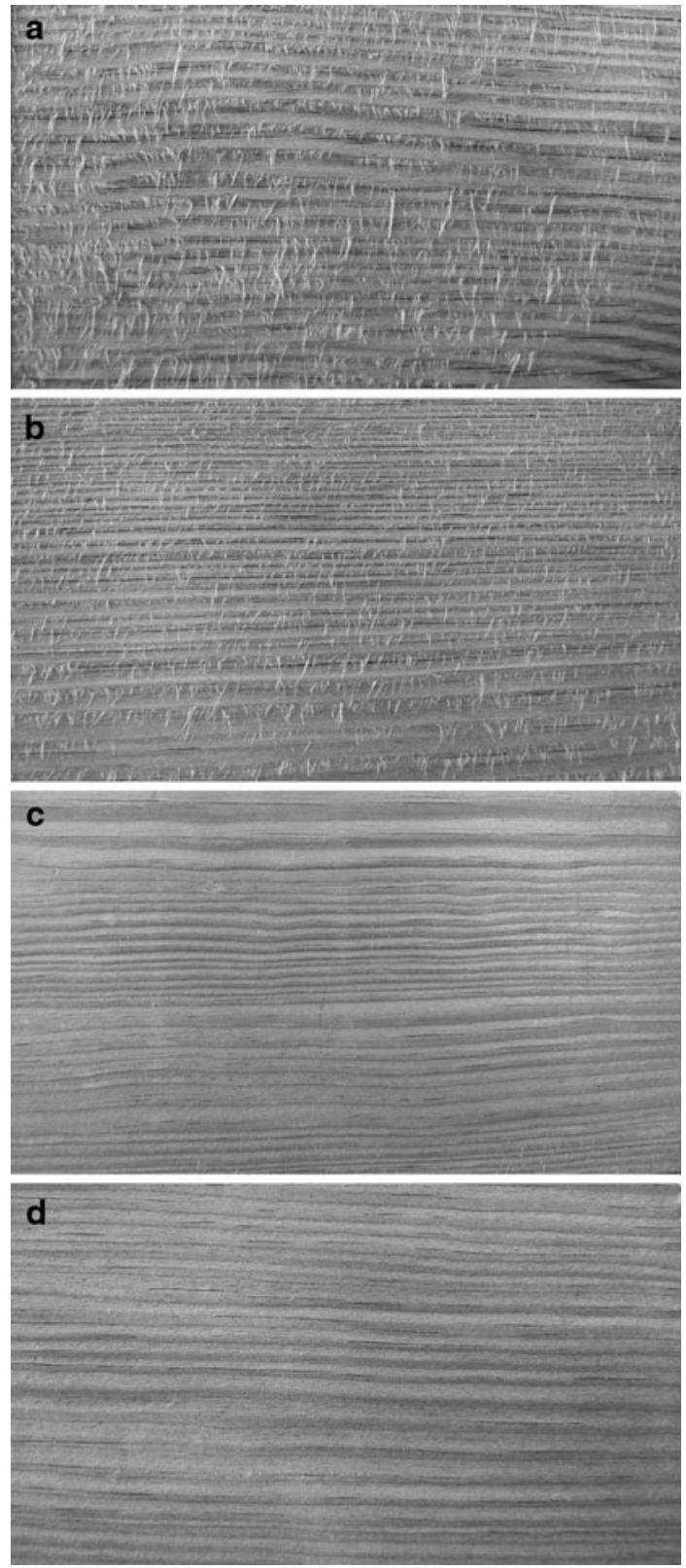

maximum moisture content of the unmodified boards reached $37 \%$, while that of boards modified with 1.2 and $2.0 \mathrm{~mol}^{-1} \mathrm{GA}$ remained below $20 \%$.

The lower moisture uptake by the modified boards in the initial 6 months of weathering is mainly attributed to the reaction of GA with cell wall polymers, where three resulting effects play a role: (1) Cross-linking makes the cell wall stiff, and the 
Table 1 Surface crack ranking (CR) of untreated and treated wood after weathering

\begin{tabular}{lllllll}
\hline $\begin{array}{l}\text { GA concentration } \\
\left(\mathrm{mol} \mathrm{l}^{-1}\right)\end{array}$ & \multicolumn{5}{l}{ Exposure time (month) } \\
\cline { 2 - 6 } & 3 & 6 & 9 & 12 & 15 & 18 \\
\hline 0.0 & 0 & 1 & 2 & 3 & 3 & 4 \\
0.4 & 0 & 1 & 1 & 1 & 2 & 3 \\
1.2 & 0 & 0 & 1 & 1 & 2 & 2 \\
2.0 & 0 & 0 & 0 & 1 & 2 & 2
\end{tabular}

The cracking is classified into five levels according to ISO 4628-4; CR $=0$ : no cracks; CR $=1$ : very few cracks; $\mathrm{CR}=2$ : a few cracks permitted; $\mathrm{CR}=3$ : a moderate amount of cracks permitted; $\mathrm{CR}=4: \mathrm{a}$ considerable amount of cracks permitted; $\mathrm{CR}=5$ : dense pattern of cracks $(n=4)$

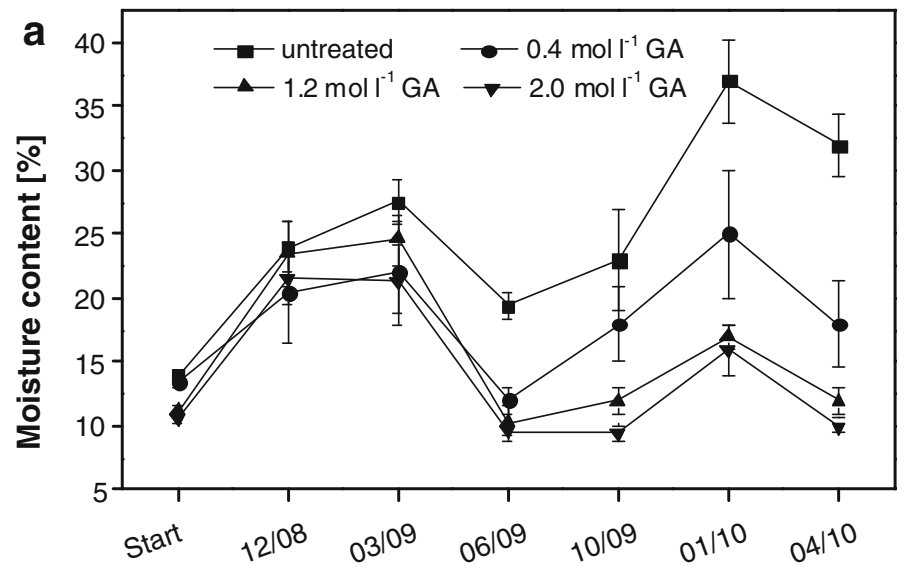

Exposure time [mm/yy]

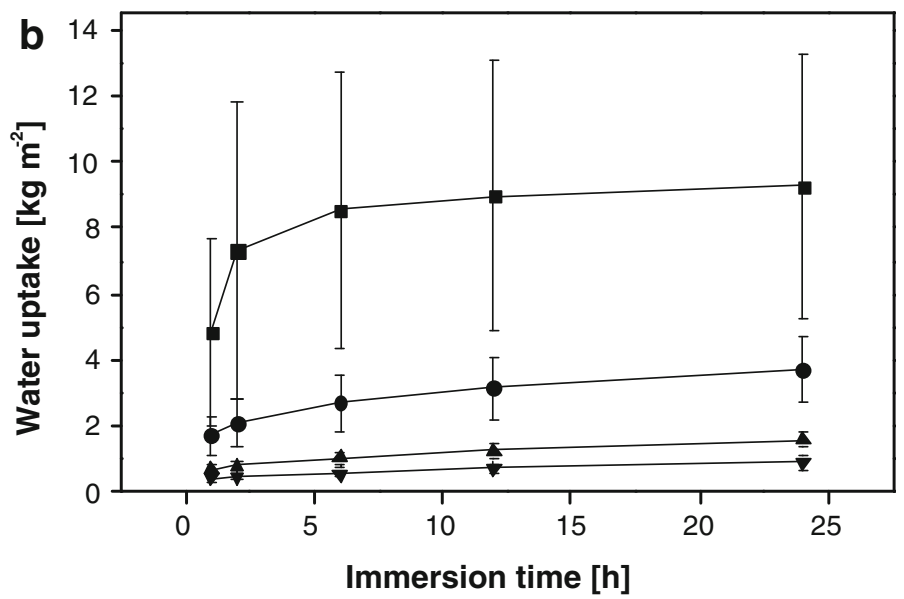

Fig. 5 Moisture content of boards during outdoor exposure (a) and capillary water uptake after 18 months of exposure (b). $(n=4 \pm \mathrm{SD})$ 
swelling is thereby restrained. As a result, the ability of water to open nano-pores by swelling the cell wall and thereby to generate new sites for moisture sorption is reduced (Xie et al. 2011); (2) cell wall bulking reduces the micro-pores which are available for water sorption (Yasuda et al. 1995; Xiao et al. 2010a); and (3) the hydroxyl groups of cell wall polymers are blocked by reacting with the aldehyde groups of GA and are therefore not available for hydrogen bonding of water.

After 9 months of weathering, the moisture differences between the unmodified and modified boards were apparently increased (Fig. 5a). In addition to the effects described above, the higher moisture content in the controls can be explained by the formation of more checks and cracks on the surface of the unmodified boards, which enhances the capillary water uptake. Moreover, the loose, hairy tracheids might enhance the adhesion of liquid water due to a greater surface area and act as wicks, which promote the transport of water into the wood.

\section{Capillary water uptake after 18 months of natural weathering}

Capillary water uptake through the weathered surface of the boards was determined after 18 months of exposure (Fig. 5b). The unmodified boards took up water very fast within the first hour and reached an equilibrium state $\left(9 \mathrm{~kg} \mathrm{~m}^{-2}\right)$ after $12 \mathrm{~h}$ of immersion. The high water uptake of unmodified wood is mainly attributed to the formation of surface cracks and surface delignification. After $2 \mathrm{~h}$, the water was observed on the top surface of the unmodified specimens, showing that water has penetrated through the whole board (not shown). Treatment with 0.4 mol $1^{-1} \mathrm{GA}$ significantly reduced the water uptake by the boards. The amount of water uptake by the boards modified with 1.2 and $2.0 \mathrm{~mol} \mathrm{l}^{-1} \mathrm{GA}$ only increased slowly and was nine times less than that taken up by the unmodified controls after $24 \mathrm{~h}$. The reduced water uptake can be attributed to the hydrophobation effect of GA, less surface erosion (particularly of lignin), fewer surface cracks due to improved dimensional stability and the absence of loose fibres on the surface exerting a wick-like effect.

\section{Penetration of blue stain into the wood}

Microscopic examination of the unmodified panels revealed that colonisation with fungi started to grow from the weathered surfaces, reaching the interior parts of the boards through the ray cells (Figs. 6a and 7a). In all GA-modified boards, fungal colonisation was restricted to the part close to the surfaces, while the parts below did not show any evidence of blue stain (Figs. 6b-d and 7b-d).

In the boards modified with 0.4 and $1.2 \mathrm{~mol}^{-1} \mathrm{GA}$, the hyphae were not able to penetrate further than approximately 3-5 mm from the weathered surface (Fig. 6b, c). Treatment of boards with $2.0 \mathrm{~mol}^{-1} \mathrm{GA}$ further restrained fungal growth to approximately half of the penetration depths noticed for the $1.2 \mathrm{~mol}^{-1}$ - treatment (Fig. 6d). However, hyphae occurred in greater amounts on the surface layers of boards modified with 2.0 mol $1^{-1} \mathrm{GA}$ as compared to those modified with 0.4 and $1.2 \mathrm{~mol} \mathrm{l}^{-1} \mathrm{GA}$ (Fig. 7d). The lower degree of blue stain colonisation in the GAmodified boards can be explained by changes in the water-related properties of wood, which reportedly result in a reduced availability of water in the lumens and 

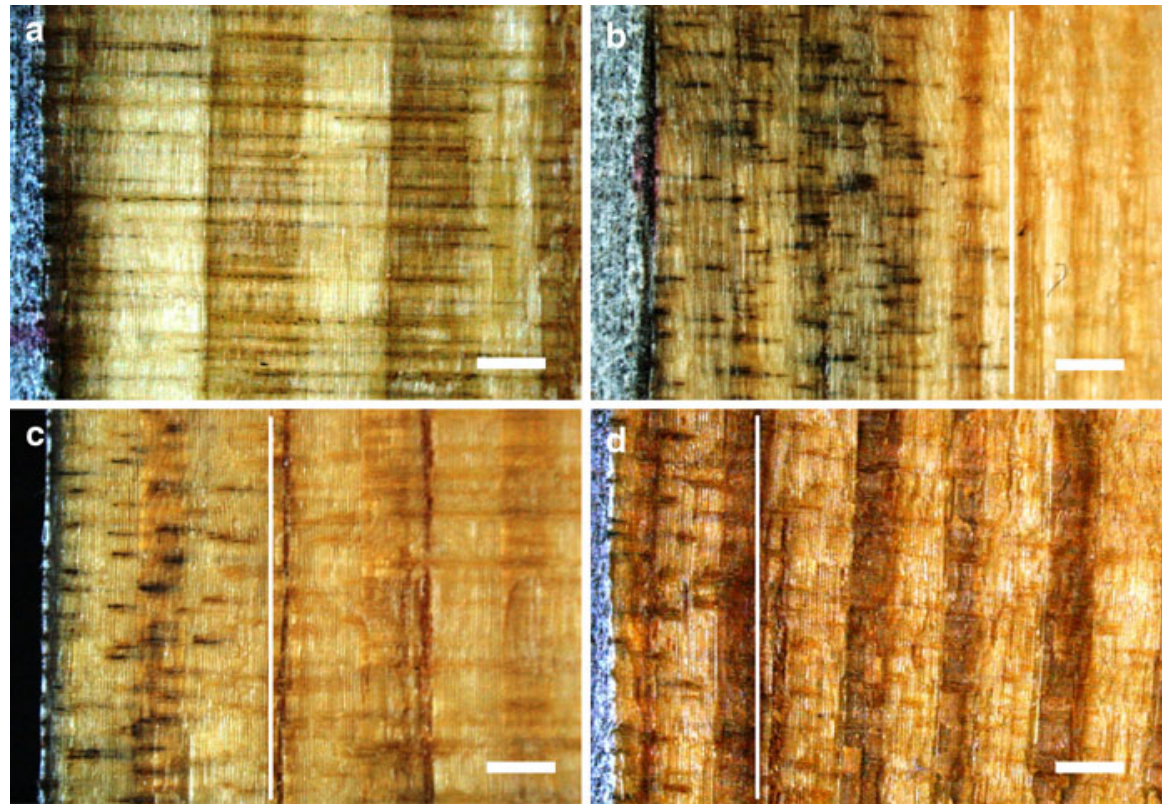

Fig. 6 Stereoscope micrographs showing radial penetration of blue stain hyphae close to the weathered surface (the exposed surface is on the left side of each micrograph) of an untreated board (a) and in boards treated with b $0.4, \mathbf{c} 1.2$ and $\mathbf{d} 2.0 \mathrm{~g} \mathrm{~mol}^{-1}$ glutaraldehyde; scale bars $=1 \mathrm{~mm}$. The white lines indicate the approximate front of hyphal penetration

cell walls (Xiao et al. 2010a). Higher amounts of hyphal mass on boards modified with $2.0 \mathrm{~mol}^{-1} \mathrm{GA}$ are assumed to be due to the presence of small voids on the surface formed after removal of lignin and cracking of the tracheids in the grain direction; these voids are able to accommodate more spores and hyphae than those on unmodified wood (see Fig. 9c, d). In addition, the surfaces of the GA-modified boards might be eroded with a minor rate than those of the unmodified ones because of the higher photo-stability of the former. This might result in a greater accumulation of mycelium on the GA-modified surfaces. Treatment of the wood substrate with DMDHEU was shown to reduce blue stain colonisation of wood in a similar pattern (Xie et al. 2008, Adamopoulos et al. 2011).

\section{Electron microscopy}

Compared to the unweathered micro-veneer strip (Fig. 8a), the cell walls of the unmodified strip were obviously eroded and thinned after $168 \mathrm{~h}$ of artificial weathering (Fig. 8c). The tracheids were wrinkled and deformed, and intercellular cracks developed due to weathering. The bordered pits exhibited severe checks along the microfibril direction (Fig. 8c). Treatment with $2.0 \mathrm{~mol} 1^{-1}$ GA (11\% WPG) apparently improved the resistance against weathering erosion (Fig. 8e). Cell wall thinning, wrinkling and deformation can also be observed, but the extent of degradation was considerably less than in the weathered control veneer. The 

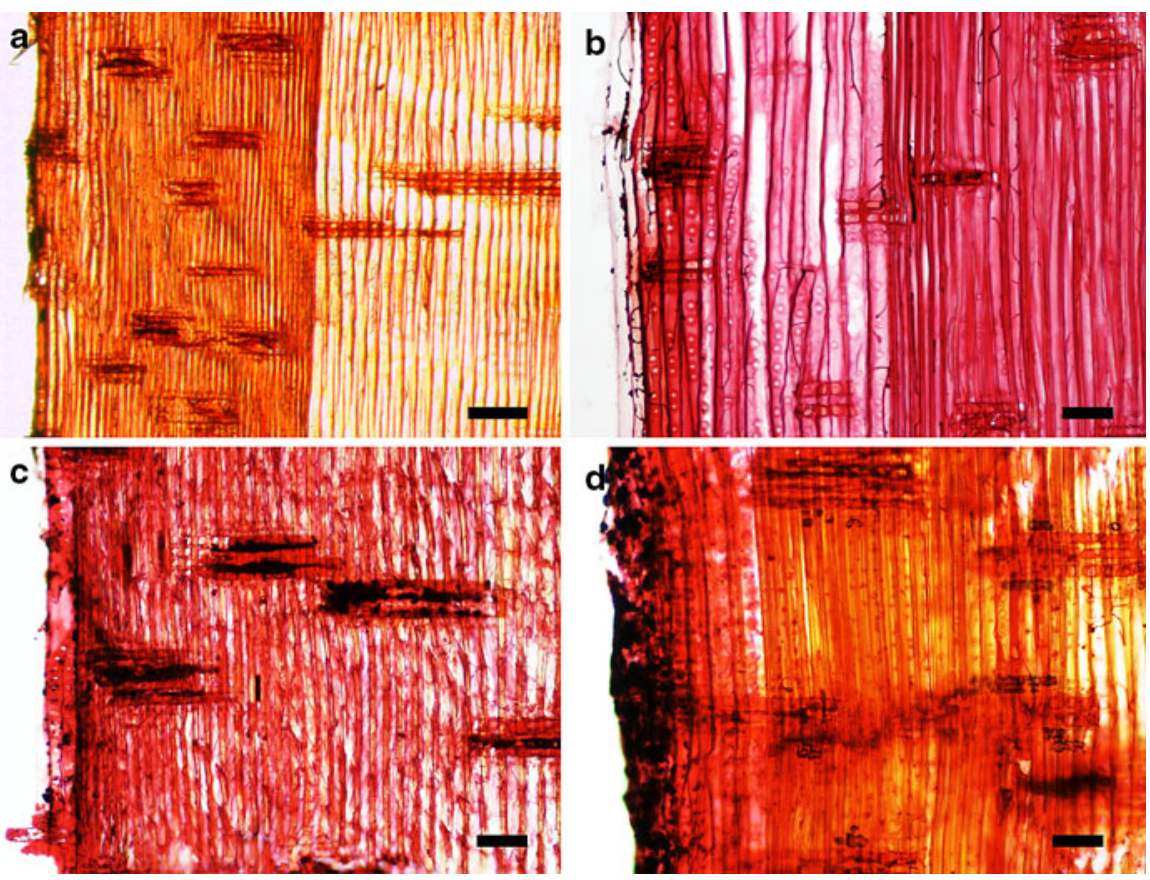

Fig. 7 Light micrographs showing radial penetration of blue stain hyphae close to the weathered surface (the exposed surface is on the left side of each micrograph) of a an untreated board and in boards treated with b $0.4, \mathbf{c} 1.2$ and $\mathbf{d} 2.0 \mathrm{~g} \mathrm{~mol}^{-1}$ glutaraldehyde. Note a the extended spread of the hyphae through the ray cells in the untreated boards, the restriction of the hyphae close to the surfaces of boards treated with b $0.4, \mathbf{c} 1.2$ and $\mathbf{d ~} 2.0 \mathrm{~g} \mathrm{~mol}^{-1}$, and the $\mathbf{d}$ higher accumulation of fungal hyphae close to the surface of the board treated with $2.0 \mathrm{~g} \mathrm{~mol}^{-1}$. Scale bars in $\mathbf{a}=200 \mu \mathrm{m}$; in $\mathbf{b}-\mathbf{d}=100 \mu \mathrm{m}$

window-like cross-field pits of the unmodified veneer were torn and eroded after weathering (Fig. 8d) as compared to those of the unmodified, unweathered strip (Fig. 8b). There were also considerable cracks and wrinkles formed on the crossfield pits of the modified veneer (Fig. 8f); however, the pits were less eroded than those of unmodified wood after weathering. In general, the latewood cells of GAmodified veneers displayed considerable resistance to weathering, and there appeared minor differences between unmodified and modified wood after weathering (not shown).

The surface tracheids of the naturally weathered, unmodified boards were detached from the tissue compound and peeled off the subjacent cell layer (Fig. 9a) as also observed macroscopically (Fig. 4a). The separated tracheids retained their integrity and exhibited a smooth surface (Fig. 9b). This has been attributed to the degradation of middle lamella substance, which has the function of gluing the cells together (see above, Hon 2001). In comparison with the unmodified wood, the modified wood exhibited less detachment of tracheids from the surface (Fig. 9c).

Intracellular cracks were observed along both the transverse and longitudinal directions (Fig. 9c, d). However, these fractured cell pieces were still tightly bonded to the tissue compound and did not detach from the subjacent cell layer as observed 

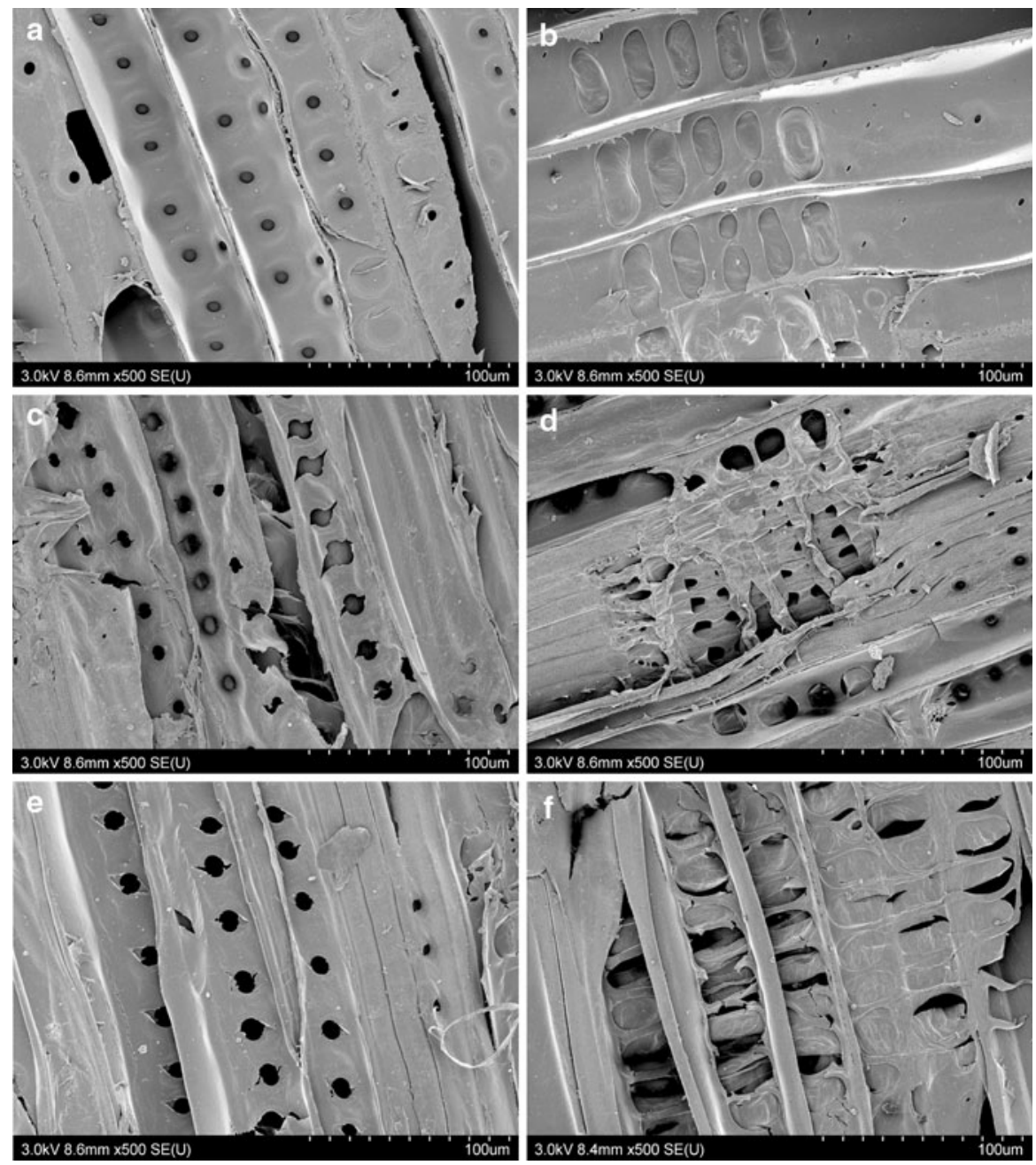

Fig. 8 Photomicrographs of Scots pine micro-veneers after artificial weathering. a Tracheids in untreated and unweathered veneers; $\mathbf{b}$ window-like cross-field pits in untreated and unweathered veneers; $\mathbf{c}$ tracheids in untreated veneers after $168 \mathrm{~h}$ weathering; $\mathbf{d}$ window-like cross-field pits in untreated veneers after $168 \mathrm{~h}$ weathering; e tracheids in veneers modified with $2.0 \mathrm{~g} \mathrm{~mol}^{-1} \mathrm{GA}$ after $168 \mathrm{~h}$ weathering; $\mathbf{f}$ window-like cross-field pits in veneers modified with $2.0 \mathrm{~g} \mathrm{~mol}^{-1} \mathrm{GA}$ after $168 \mathrm{~h}$ weathering

for the tracheids of the unmodified boards. The intracellular cracks formed in GA-modified wood can be due to the cross-linking of cell wall polymers by GA and the hydrolysis of polysaccharides, which results in the embrittlement of wood (Xiao et al. 2010b). The latter effects reduce the flexibility of the tracheids with regard to water-related dimensional changes. Especially, the shrinking of wood during drying of the surface might therefore cause transversal cracking of the tracheids due to the rigid structure of the modified tissue and the reduced tensile strength reported previously (Xiao et al. 2010b). The minor degree of peeling of the tracheids from 

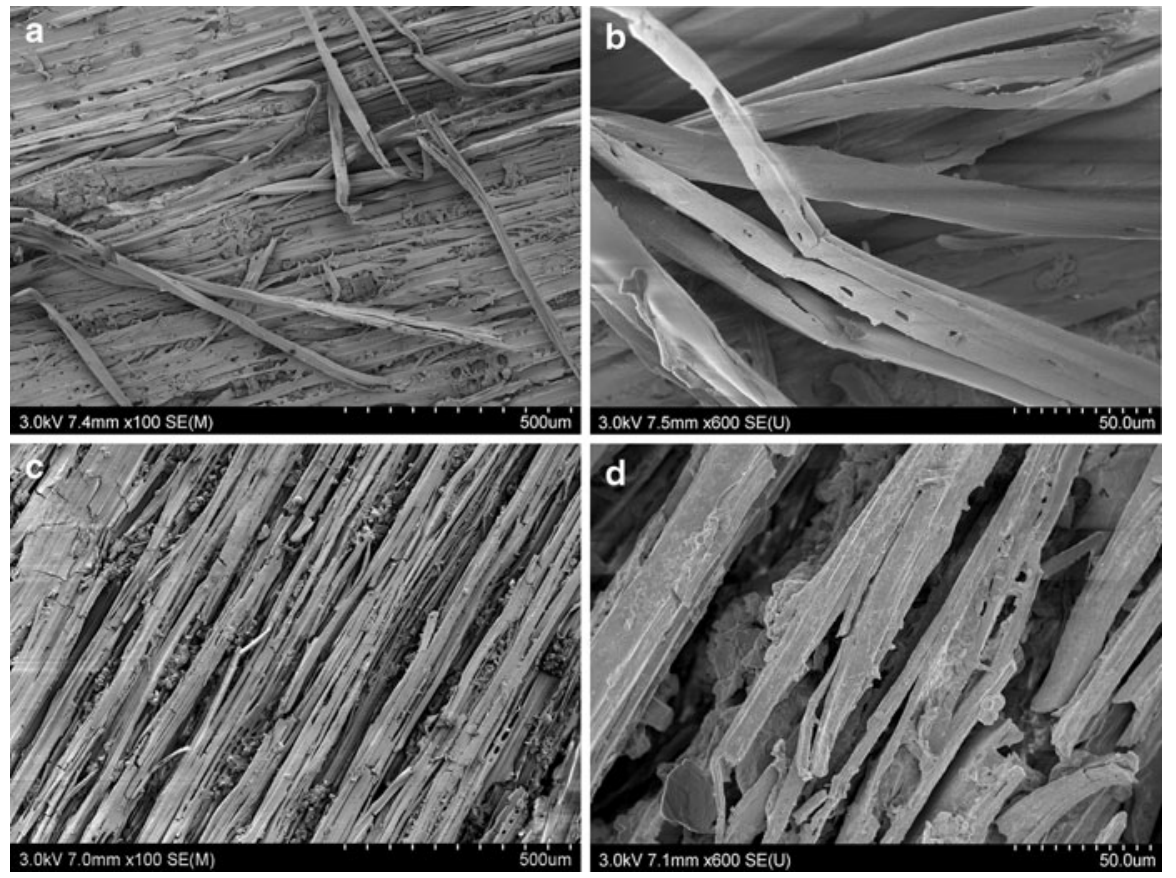

Fig. 9 Photomicrographs of Scots pine untreated (a, b) and treated with $2.0 \mathrm{~mol}^{-1}$ glutaraldehyde (c, d) after 18 months of outside weathering

the surface of GA-modified wood may be due to the improved photo-stability of lignin (see above) and the immediate erosion of debris from the cracked tracheids.

\section{Conclusion}

GA treatment restricted the photo-degradation of lignin during artificial weathering. The effect of the treatment on the photo-stability of polysaccharides was not assessable by means of micro-tensile testing because the chemical treatment itself induced high strength loss. GA-treated wood exhibited fewer surface cracking and less moisture sorption and water uptake. Blue stain colonisation was also reduced considerably. GA is, thus, considered as a suitable modifying agent to improve the performance of wood used outdoors.

Acknowledgments Zefang Xiao would like to thank the German Academic Exchange Service (DAAD) for the STIBET (Stipendien- und Betreuungsprogramm) grant. Yanjun Xie thanks the National Natural Science Foundation of China for the support (Project Nos. 31010103905 and 31070507). The support from the Special Funds for Scientific Research on Public Causes of Forestry (No. 201004006-4) is also acknowledged.

Open Access This article is distributed under the terms of the Creative Commons Attribution Noncommercial License which permits any noncommercial use, distribution, and reproduction in any medium, provided the original author(s) and source are credited. 


\section{References}

Adamopoulos S, Xie Y, Militz H (2011) Distribution of blue stain in untreated and DMDHEU treated Scots pine sapwood panels after six years of outdoor weathering. Eur J Wood Prod 69(2):333-336

Chang S-T, Chang H-T (2001) Comparisons of the photostability of esterified wood. Polym Degrad Stab 71:261-266

EN 927-3 (2006) Paints and varnishes — coating materials and coating systems for exterior wood-part 3: natural weathering test. European committee for standardisation (CEN), Brussels, Belgium

Evans PD (1988) A note on assessing the deterioration of thin wood veneers during weathering. Wood Fiber Sci 20(4):487-492

Evans PD (1998) Weather resistance of wood esterified with dicarboxylic acid anhydrides. Holz Roh Werkst 56(5):294

Evans PD (2008) Weathering and photoprotection of wood. In: Schultz TP, Militz H, Freeman MH, Goodell B, Nicholas DD (eds) Development of commercial wood preservatives: efficacy, environmental, and health issues. ACS symposium series 982. American Chemistry Society, Washington, DC, pp 69-117

Evans PD (2009) Review of the weathering and photostability of modified wood. Wood Mater Sci Eng 4(1):2-13

Evans PD, Schmalzl KJ (1989) A quantitative weathering study of wood surfaces modified by chromium VI and iron III compounds. Part 1. Loss in zero-span tensile strength and weight of thin wood veneers. Holzforschung 43:289-292

Evans PD, Thay PD, Schmalzl KJ (1996) Degradation of surfaces during natural weathering. Effects on lignin and cellulose and on the adhesion of acrylic latex primers. Wood Sci Technol 30(6):411-422

Evans PD, Wallis AFA, Owen NL (2000) Weathering of chemically modified wood surfaces: natural weathering of Scots pine acetylated to different weight gains. Wood Sci Technol 34:151-165

Evans PD, Owen NL, Schmid S, Webster RD (2002) Weathering and photostability of benzoylated wood. Polym Degrad Stabil 76:291-303

Evans PD, Urban K, Chowdhury MJA (2008) Surface checking of wood is increased by photodegradation caused by ultraviolet and visible light. Wood Sci Technol 42:251-265

Faix O, Grünwald C, Beinhoff O (1992) Determination of phenolic hydroxyl group content of milled wood lignins (MWL's) from different botanical origins using selective aminolysis, FTIR, 1H-NMR, and UV spectroscopy. Holzforschung 46:425-432

Feist WC (1982) Weathering of wood in structural uses. In: Meyers R, Kellogg R (eds) Structural uses of wood in adverse environments. Van Nostrand Reinhold Company, New York, pp 156-178

Feist WC, Hon DN-S (1984) Chemistry of weathering and protection. In: Rowell RM (ed) Chemistry of solid wood. ACS, Washington, DC, pp 401-454

Feist WC, Rowell RM (1982) Ultraviolet degradation and accelerated weathering of chemically modified wood. In: Hon DN-S (ed) Graft copolymerisation of lignocellulosic fibres. ACS, Washington, DC, pp 349-370

Feist WC, Rowell RM, Ellis WD (1991) Moisture sorption and accelerated weathering of acetylated and methacrylated aspen. Wood Fibre Sci 23:128-136

Hill CAS (2006) Wood modification: chemical, thermal and other processes. Wiley, Chichester

Hill CAS, Farahani MRM, Hale MDC (2004) The use of organo alkoxysilane coupling agents for wood preservation. Holzforschung 58:316-325

Hon DN-S (2001) Weathering and photochemistry of wood. In: Hon DN-S, Shiraishi N (eds) Wood and cellulose chemistry. Marcel Dekker, New York, pp 512-546

ISO 4628-4 (1982) Paints and vanishes-evaluation of degradation of paint coatings-designation of intensity, quantity and size of common types of defect. Part 4: designation of degree of cracking

Jebrane M, Sebe G, Cullis I, Evans PD (2009) Photostabilization of wood using aromatic vinyl esters. Polym Degrad Stabil 94:151-157

Rowell RM, Feist WC, Ellis WD (1981) Weathering of chemically modified southern pine. Wood Sci 13:202-208

Schmalzl KJ, Forsyth CM, Evans PD (1995) The reaction of guaiacol with iron III and chromium VI compounds as a model for wood surface modification. Wood Sci Technol 29:307-319

Schmalzl KJ, Forsyth CM, Evans PD (2003) Evidence for the formation of chromium (III) diphenoquinone complexes during oxidation of guaiacol and 2, 6-dimethoxyphenol with chromic acid. Polym Degrad Stabil 82:399-407 
Weaver JW, Nielson JF, Goldstein IS (1960) Dimensional stabilization of wood with aldehydes and related compounds. Forest Prod J 10:306-310

Williams SR (2010) Finishing of wood. In: Wood Handbook. General Technical Report FPL-GTR-190. Madison, WI: U.S. Department of Agriculture, Forest Service, Forest Products Laboratory, Chapter 16:1-39

Xiao Z, Xie Y, Militz H, Mai C (2010a) Effect of glutaraldehyde on water related properties of solid wood. Holzforschung 64:475-482

Xiao Z, Xie Y, Militz H, Mai C (2010b) Effects of glutaraldehyde on the mechanical properties of solid wood. Holzforschung 64:483-488

Xie Y, Krause A, Mai C, Militz H, Richter K, Urban K, Evans PD (2005) Weathering of wood modified with the N-methylol compound 1, 3-dimethylol-4, 5-dihydroxyethyleneurea. Polym Degrad Stabil 89:189-199

Xie Y, Krause A, Militz H, Turkulin H, Richter K, Mai C (2007) Effect of treatments with 1, 3-dimethylol-4, 5-dihydroxyethyleneurea (DMDHEU) on the tensile properties of wood. Holzforschung 61:43-50

Xie Y, Krause A, Militz H, Mai C (2008) Weathering of uncoated and coated wood treated with methylated 1, 3-dimethylol-4, 5-dihydroxyethyleneurea (mDMDHEU). Holz Roh Werkst 66:455-464

Xie Y, Xiao Z, Goodell B, Jellison J, Militz H, Mai C (2010) Degradation of wood veneers by Fenton's reagents: effects of wood constituents and low molecular weight phenolic compounds on hydrogen peroxide decomposition and wood tensile strength loss. Holzforschung 64:375-383

Xie Y, Hill CAS, Xiao Z, Mai C, Militz H (2011) Dynamic water vapour sorption properties of wood treated with glutaraldehyde. Wood Sci Technol 45:49-61

Yasuda R, Minato K (1994) Chemical modification of wood by non-formaldehyde cross-linking reagents. Part 1. Improvement of dimensional stability and acoustic properties. Wood Sci Technol 28:101-110

Yasuda R, Minato K, Norimoto M (1995) Moisture adsorption thermodynamics of chemically modified wood. Holzforschung 49:548-554

Yusuf S (1996) Properties enhancement of wood by cross-linking formation and its application to the reconstituted wood products. Wood Res 83:140-210 